\title{
EFIKASI SUPLEMEN BESI-MULTIVITAMIN UNTUK PERBAIKAN STATUS BESI REMAJA WANITA
}

\author{
Dodik Briawan'; Hardinsyah'; Muhilal'; Budi Setiawan' dan Sri Anna Marliyati ${ }^{1}$ \\ 'Staf pengajar di Departemen Gizi Masyarakat, FEMA, IPB \\ ${ }^{2}$ Staf pengajar di Fakultas Kedokteran, UNPAD Bandung
}

\section{ABSTRACT \\ EFFICACY OF IRON-MULTIVITAMIN SUPPLEMENT FOR IMPROVING THE IRON STATUS OF ADOLESCENT FEMALES}

The study was aimed to analyze the efficacy of supplementation iron-multivitamin for improving the iron status of adolescent females through the double-blind trial. Subjects were 224 of the first grade university students (IPB) who were randomly allocated to three study groups through a double blind trial. The first group received only placebo (control group); the second group received $60 \mathrm{mg}$ iron, $250 \mathrm{ug}$ folate (B-F group); the third group received $60 \mathrm{mg}$ iron, $800 \mathrm{ug}$ folate, $4200 \mathrm{ug}$ retinyl acetate, $500 \mathrm{mg}$ vitamin C, and 16.8 ug vitamin B12 (B-MV group). All supplements were distributed and consumed weekly during 25 weeks. The mean changes in $\mathrm{Hb}$, STfR and SF among the groups were tested with Ancova and adjusted with BMl; capsule compliance; food/snack compliance; adequacy of energy, protein, vitamin A, vitamin C, iron; and baseline value of $\mathrm{Hb}, \mathrm{STfR}, \mathrm{SF}$. The results showed the demographics and nutritional characteristics of samples were not significantly different. At the baseline, the mean of haemoglobin $(\mathrm{Hb}=126.2 \pm 13.1 \mathrm{~g} / \mathrm{l})$ and serum ferritin $(\mathrm{SF}=18.3 \pm 15.9 \mathrm{ug} / \mathrm{l})$ were not significantly different among the three groups $(\mathrm{p}<0.05)$. However, the serum transferrin receptor (STfR) was lower in the control $(5.8 \pm 3.2 \mathrm{mg} / \mathrm{l})$ than B-F $(7.9 \pm 4.4 \mathrm{mg} / \mathrm{l})$ and B-MV $(11.8 \pm 5.5 \mathrm{mg} / \mathrm{l})$. After 25 week of supplementation, the mean change of hemoglobin was not different among the three groups (10.1 $\mathrm{g} / ; ; p>0.05)$. The B-MV group significantly lower decreased in STfR $(-4.2 \mathrm{mg} / \mathrm{l})$ and higher increased in SF $(+13.4 \mathrm{ug} / \mathrm{l})$ compared to B-F and control group $(p<0.05)$. Meanwhile, only the STfR in B-F group (-1.3 ug/l) was significantly lower than control group $(p<0.05)$. This implied the important of the multi-vitamin to complement the iron supplementation.

Keywords: haemoglobin $(\mathrm{Hb})$, serum transferrin receptor (STfR), serum ferritin (SF), iron status, iron-multivitamin, iron-folate, adolescent female

\section{PENDAHULUAN}

A nemia merupakan salah satu indikator rendahnya status besi yang paling banyak dijumpai di berbagai negara, dan menjadi masalah global karena jumlah penderita yang sangat besar yaitu hampir dua milyar $(30 \%)$ dari populasi dunia. Program suplementasi besi-folat telah dilakukan di berbagai negara sejak tahun 1970-an, namun perkembangannya masih dinilai sangat lambat. Pelaksanaan program suplementasi besi telah mengalami beberapa perubahan sesuai dengan rekomendasi WHO diantaranya tentang dosis, jenis zat gizi, lama intervensi, dan sasarannya. Namun penambahan multivitamin baru sebatas pada tahap penelitian yang belum konklusif untuk dapat dijadikan rekomendasi internasional. Saat ini target program suplementasi diperluas tidak hanya kepada ibu hamil, tetapi juga anak balita, anak sekolah, dan wanita usia subur (Ekstrom, 2001). Studi efikasi dan efektifnes suplementasi berbagai zat gizi mikro (multimicro nutrients) sampai sekarang terus dilakukan dan masih terbuka untuk dikembangkan guna mendukung keberhasilan program perbaikan status gizi 
besi di masa mendatang.

Pada siklus hidup manusia, remaja wanita (10-19 tahun) merupakan salah satu kelompok yang rawan terhadap anemia. Data SKRT 2001 menunjukkan prevalensi anemia pada remaja wanita sebesar 26,5 persen (Depkes, 2007), dengan jumlah populasi remaja wanita di Indonesia tahun 2005 sekitar 20 juta. Akibat anemia gizi besi pada remaja selain menurunkan produktivitas kerja juga akan menurunkan kemampuan akademis (Beard, 2001; INACG, 2004). Kehamilan pada usia remaja yang juga menderita anemia akan menyebabkan kematian ibu, bayi, atau berat bayi lahir rendah. Oleh karena itu, sasaran program perbaikan gizi pada kelompok remaja wanita dianggap strategis di dalam upaya memutus siklus masalah gizi.

Sebanyak 50 persen kasus anemia diakibatkan oleh defisiensi zat besi (INACG 2004). Selain itu, rendahnya status besi juga terkait dengan defisit zat gizi mikro lainnya seperti asam folat, vitamin $A$, vitamin C, vitamin B12 dan riboflavin (Beard, 2000; Allen dan Casterin-Sabell, 2001), dan selebihnya dapat terjadi karena infeksi/inflamasi. Tidak banyak studi tentang prevalensi defiensi zat gizi mikro di Indonesia, namun karena rendahnya kualitas konsumsi pangan masyarakat maka kemungkinan besar juga akan defisit vitamin. Beberapa studi yang ada, diantaranya, prevalensi defisit vitamin A pada remaja di Tangerang dan Jakarta sebesar 7-20 persen (Dillon, 2005); di Surabaya, Bangkalan, Sampang sebesar 5-7 persen (Soekarjo et al. 2004). Survey di lima negara Amerika Latin prevalensi defisiensi vitamin B12 cukup merata antar negara yaitu 40-50 persen, sedangkan defisiensi asam folat beragam antara 5-89 persen (Allen, 2004).

Berdasarkan data tersebut di atas, maka untuk suplementasi zat besi diperlukan tambahan zat gizi mikro lainnya. Secara terpisah peneliti lainnya telah melakukan penambahan zat gizi lain tersebut. Sehingga perlu dilakukan studi lanjutan untuk mengetahui pengaruh penggabungan beberapa zat gizi tersebut secara bersamasama terhadap perbaikan status besi. Studi efikasi suplementasi besi-multivitamin ini dilakukan pada sampel yang kecukupan energi dan proteinnya sudah relatif terpenuhi. Energi dan protein diperlukan pada proses metabolisme zat besi di dalam tubuh mulai dari absorpsi, transportasi, dan mobilisasi simpanannya (Wessling-Resnick, 2000).

Tujuan umum penelitian adalah untuk mengetahui efikasi pemberian suplemen besi-multi vitamin untuk perbaikan status besi pada remaja wanita. Secara khusus tujuan penelitian adalah:

1. Membandingkan efikasi suplemen besimultivitamin (B-MV) dengan suplemen standar pemerintah berupa besi-folat (B-F) terhadap perbaikan status besi

2. Membandingkan efikasi suplemen besimultivitamin (B-MV) dengan kontrol terhadap perbaikan status besi

3. Membandingkan efikasi suplemen besifolat (B-F) dengan kontrol terhadap perbaikan status besi

\section{BAHAN DAN CARA}

\section{Desain, Sampel dan Waktu}

Desain penelitian adalah randomized control trial (RCT). Sampel dikelompokkan menjadi tiga perlakuan yang terdiri dari kontrol, besi-folat (B-F) dan besi-multivitamin (B-MV) (Tabel 1). Sampel diberi kapsul satu kali seminggu selama 25 minggu, dan mereka tidak mengetahui jenis kapsul yang diberikan. Studi ini mendapatkan ethical clearance dari Badan Penelitian dan Pengembangan Kesehatan (Depkes).

Penggunaan dosis suplemen besi-folat atau kapsul standar berdasarkan rekomendasi Departemen Kesehatan RI (2003). Selain kontrol, perlakuan kapsul standar ini digunakan sebagai pembanding efikasinya terhadap sampel yang diberi besimultivitamin. Dosis kapsul besi-multivitamin diformulasikan untuk lebih meningkatkan efektifitas metabolisme zat besi serta proses eritropoiesis. Dosis zat besi ditetapkan 60 $\mathrm{mg}$, karena review berbagai studi dengan dosis $60 \mathrm{mg}$ mampu meningkatkan kadar $\mathrm{Hb}$ secara signifikan. Dosis asam folat pada 
studi ini sebesar tiga kali $A K G$, dosis vitamin C, B12, dan vitamin A sebesar tujuh kali AKG (WNPG, 2004).

Sampel penelitian adalah remaja wanita yang berusia 17-19 tahun (late adolescent). Jumlah minimal sampel ditetapkan dengan asumsi $\alpha=5$ persen power of test $=90$ persen, $\mathrm{SD}=10,6 \mathrm{~g} / \mathrm{l}, \mathrm{d}=7,1 \mathrm{~g} / \mathrm{l}$ (Angeles-Agdeppa et al.1997; Dillon 2005), sehingga diperoleh jumlah minimum 47 orang per perlakuan. Apabila diasumsikan drop-out 10-15 persen maka jumlah sampel minimal 52-54 orang. Sampel diambil dari peserta penerima PMT mahasiswi TPB-IPB tahun 2005/2006 yang bersedia ikut kegiatan (informed concent) kemudian dibagi menjadi tiga kelompok secara acak (random assignment), sehingga diperoleh masing-masing sebanyak 74-75 orang per perlakuan.

Pertimbangan peneliti untuk melakukan suplementasi pada peserta penerima PMT adalah untuk homogenisasi subyek agar terjadi optimalisasi metabolisme zat besi. Studi pendahuluan menunjukkan mahasiswi IPB rata-rata mengalami defisit energi sebesar 250-400 kkal, sehingga mereka memperoleh tambahan energi setara dengan jumlah tersebut dari snack dan minuman berupa kombinasi aneka biskuit dan susu, roti dan juice setiap hari selama 25 minggu. Sehingga dengan homoenisasi ini, kemungkinan sampel tidak dalam kondisi defisit zat gizi makro. Proses metabolisme zat besi di dalam tubuh mulai dari absorpsi, transportasi, dan mobilisasi simpanannya tidak terlepas dari keberadaan penyediaan energi dan protein tubuh (Beard et al. 1996).

Suplementasi dilakukan selama 25 minggu antara bulan November 2005 - Juni 2006. Seminggu sebelum intervensi kepada seluruh sampel diberikan kapsul antihelminth (pirantel pamoat $250 \mathrm{mg}$ ). Kapsul suplemen didistribusikan setiap hari rabu sore jam 16.00-18.00, di Kantor BP Asrama IPB. Untuk mengawasi compliance, diusahakan kapsul langsung diminum di tempat, dengan air minum di depan peneliti yang dibantu dua petugas distribusi. Selama suplementasi, sampel melaporkan (self reported) penggunaan kapsul yang telah diberikan dengan cara mengisi formulir, termasuk melaporkan manfaat yang dirasakan dan keluhan yang ditimbulkan.

\section{Jenis dan Cara Pengumpulan Data}

Sebelum suplementasi, sampel diperiksa status kesehatan, pengukuran antropometri, pengambilan sampel darah, dan dilanjutkan dengan serangkaian pengisian kuesioner. Untuk pengukuran berat dan tinggi badan menggunakan alat timbang (SECA skala terkecil $0,1 \mathrm{~kg}$ ) dan stadiometer (skala terkecil 0,1 cm). Pengumpulan data dilakukan oleh peneliti yang dibantu tiga orang asisten untuk verifikasi pengisian kuesioner, tiga orang petugas klinik untuk pengambilan darah, dan seorang dokter medis untuk pemeriksaan kesehatan. Sebelumnya petugas diberi penjelasan tentang data yang akan dikumpulkan dan cara pengumpulannya.

Data konsumsi pangan yang dikumpulkan meliputi konsumsi di hari kuliah dan hari libur. Formulir konsumsi pangan diberikan kepada responden dan dijelaskan cara pengisiannya, meliputi jenis makanan, jumlah yang dimakan (URT), harga makanan, dan tempat membeli makanan, yang kemudian diverifikasi satu-persatu pada minggu berikutnya.

Pengambilan darah baseline dan endline dilakukan secara serentak pada pagi (jam 06.00-08.00). Analisa Hb menggunakan metode cyanmethemoglobin, analisis SF dan STfR dengan metode sandwich ELISA. Prosedur untuk analisis serum ferritin (SF) dan serum transferin receptor (STfR) mengacu metode yang dikembangkan oleh Erhard et al. (2004).

\section{Pengolahan dan Analisis Data}

Untuk menghitung tingkat kecukupan energi dan zat gizi menggunakan Angka Kecukupan Gizi hasil WNPG 2004. Kategori tingkat kecukupan energi dan protein adalah $<70$ persen defisit berat, $70-80$ persen defisit sedang, 80-90 persen defisit ringan, 90-110 persen normal, $>110$ persen kelebihan. Untuk vitamin $A$, vitamin $C$, dan zat besi menggunakan batas $2 / 3 \quad(70 \% \quad A K G)$. Kategori untuk Indeks Massa Tubuh (IMT) kurus $\left(<18,5 \mathrm{~kg} / \mathrm{m}^{2}\right)$, normal $(18,5-25,0 \mathrm{~kg} /$ 
$\left.\mathrm{m}^{2}\right)$ dan overweight/obese $\left(>25,0 \mathrm{~kg} / \mathrm{m}^{2}\right)$. Kategori anemia adalah konsentrasi $\mathrm{Hb}$ $<120,0 \mathrm{~g} / \mathrm{l}$, kategori defisiensi zat besi eritropoiesis (IDE) jika STfR $>8,3 \mathrm{mg} / \mathrm{l}$ dan kategori deplesi zat besi jika SF $<15$ ug/l.

Uji ANOVA digunakan untuk mengetahui perbedaan peubah confounder (baseline), dan selisih perubahan nilai $\mathrm{Hb}$, SF, dan STfR setelah suplementasi. Uji normalitas terhadap data biomarker menggunakan uji Kolmogorov-Smirnov, dan uji keragaman varian menggunakan Lavene test. Untuk uji siginifikansi karena tidak berdistribusi normal, data $\mathrm{Hb}$ ditransformasikan kedalam kuadratik, sedangkan STfR dan SF ditransformasi kedalam bentuk logaritma (log), namun didalam penyajian menggunakan data aktual. Uji ANCOVA digunakan untuk mengkoreksi (adjusted) peubah yang potensial menjadi perancu (confounder), yaitu: 1) konsentrasi biomarker awal $\mathrm{Hb}$, STfR, SF, 2) indeks massa tubuh, 3) compliance kapsul, 4) compliance PMT, 5) tingkat kecukupan energi, protein, zat besi, vitamin $\mathrm{A}$ dan vitamin $\mathrm{C}$.

\section{HASIL DAN BAHASAN}

\section{Karakteristik sampel}

Pada ketiga kelompok perlakuan, ratarata umur sampel 18,5 $\pm 0,6$ tahun (Tabel 2). Sebagian besar sampel $(98,5 \%)$ pada usia remaja lanjut (late adolescence) yaitu antara 17-19 tahun. Rata-rata pengeluaran bulanan sampel selama tinggal di Asrama IPB adalah Rp 476.985 \pm 177.651 Kurang lebih terdapat 20 jenis alokasi pengeluaran bulanan untuk mahasiswi. Rata-rata alokasi per bulan untuk membeli makanan Rp $212.660(44,6 \%)$, minuman $\mathrm{Rp} 32.464$ $(6,8 \%)$ dan jajanan $\operatorname{Rp} 26.819 \quad(5,7 \%)$, sehingga sebagian besar $(58,0 \%)$ alokasi pengeluaran untuk pangan. Sebanyak 20 persen sampel biasa mengeluarkan uang Rp12.500/bulan untuk membeli suplemen pangan, seperti minuman berenergi, vitamin $C$, dan serat makanan. Dengan uji Anova diantara ketiga kelompok perlakuan, ratarata peubah di atas tidak berbeda nyata $(p>0,05)$.
Rata-rata berat badan (BB) sampel adalah $46,8 \pm 5,7 \mathrm{~kg}$, dengan selang antara $33,1-64,4 \mathrm{~kg}$. Rata-rata tinggi badan (TB) pada ketiga kelompok adalah $153,7 \pm 5,5 \mathrm{~cm}$ dengan selang 138,8-166,4 cm. Rata-rata nilai IMT sampel sebelum suplementasi adalah $19,8 \mathrm{~kg} / \mathrm{m}^{2}$, dan sebanyak $24,5 \%$ berada pada kategori kurus. Dengan analisis Ancova, peubah IMT pengaruhnya tidak signifikan terhadap efikasi ketiga indikator status besi $(p>0,05)$. Pada studi crosssectional ditemukan adanya korelasi antara IMT dengan kadar $\mathrm{Hb}$ (Permaesih dan Herman 2005, Khatib et al. 2006), tetapi pada studi eksperimental lainnya nilai IMT tidak berpengaruh terhadap hemoglobin dan serum feritin (Ahmed et al. 2005, Dillon 2005).

Seluruh sampel penelitian adalah remaja yang sudah mengalami menstruasi, dan tidak mengalami gangguan menstruasi (metroragia dan meno-metroragia). Umur pertama kali sampel mengalami menstruasi (menarche) berkisar antara 10-16 tahun. Rata-rata umur menarche sampel adalah 13,0 tahun, dan diantara ketiga kelompok perlakuan tidak berbeda nyata $(p>0,05)$. Sebanyak 27,1 persen sampel sudah mengalami menstruasi sejak umur $\leq 12,0$ tahun, dan bahkan 4,9 persen sudah menstruasi sejak umur $\leq 11,0$ tahun.

Sebagian besar sampel $(80,8 \%)$ menyatakan mempunyai siklus menstruasi yang teratur. Pengertian teratur adalah jika sampel selalu mengalami menstruasi sesuai dengan siklusnya (25-35 hari). Pada sampel yang menstruasinya tidak teratur, dalam satu tahun rata-rata mengalami menstruasi sebanyak 10,2 \pm 3,9 kali. Rata-rata lama menstruasi pada seluruh sampel adalah 6,4 $\pm 1,5$ hari, dan perbedaan diantara ketiga kelompok tidak nyata. Pada sampel yang mengalami siklus menstruasi teratur, lama siklus menstruasi adalah 28,1 $\pm 3,7$ hari, dan diantara ketiga kelompok juga tidak terdapat perbedaan yang signifikan. Dengan uji Anova perbedaan lama siklus menstruasi, lama menstruasi dan siklus menstruasi dalam setahun diantara ketiga kelompok tidak berbeda nyata $(p>0,05)$. 


\section{Asupan dan Tingkat Kecukupan Gizi}

Hasil analisis konsumsi pangan dan gizi antar ketiga kelompok perlakuan relatif sama, baik antar kelompok perlakuan, sebelum dan sesudah suplementasi. Sebelum suplementasi, rata-rata asupan energi 1481 kkal, protein $36 \mathrm{~g}$, vitamin A 621 $\mathrm{RE}$, vitamin C 59,3 mg, Fe 13,7 mg per hari (Tabel 3). Dibandingkan dengan kecukupan gizi (AKG), maka tingkat kecukupan energi dan protein antara 71-78 persen. Hanya vitamin A yang sudah memenuhi AKG (>90\%), dibandingkan vitamin $C$ dan zat besi yaitu berturut-turut $68-90$ persen dan $50-55$ persen. Prevalensi kategori defisit asupan gizi mikro (vitamin $A, C$ dan zat besi) masih sangat tinggi (35-86\%). Dengan kebiasaan makan tersebut selama tinggal di Asrama, kemungkinan banyak ditemukan kasus defisiensi gizi seperti yang dilaporkan dari identifikasi kegiatan PMT, yaitu mahasiswi gizi kurang (IMT<18,5 kg/ $\mathrm{cm}^{2}$ ) 39,5 persen dan anemia 28,5 persen.

Rata-rata tingkat kepatuhan konsumsi PMT adalah 86,5 $\pm 9,2$ persen. Asupan zat gizi dari PMT dianalisis dari asupan energi, protein, vitamin $A$, vitamin $B 12$, vitamin $C$, zat besi per hari. Rata-rata asupan energi pada kontrol 294 kkal, kelompok B-F 300 kkal, dan kelompok B-MV 294 kkal. Untuk zat gizi lainnya antar kelompok relatif sama, yaitu rata-rata asupan protein sekitar $5 \mathrm{~g}$, vitamin A 68 RE, vitamin B12 0,2 mg, vitamin C $9 \mathrm{mg}$ dan zat besi 2,3 mg. Rata-rata asupan energi dan gizi dari PMT seperti vitamin $A$, vitamin $B 12$, vitamin $C$ dan zat besi diantara ketiga kelompok perlakuan tidak berbeda nyata $(p>0,05)$

Asupan zat gizi pada Tabel 3 tidak termasuk dari suplementasi besi-folat/multivitamin. Hasil penilaian konsumsi pangan setelah suplementasi (end line) terjadi peningkatan tingkat kecukupan zat gizi makro, tetapi tidak untuk zat gizi mikro. Ratarata asupan energi $1838 \mathrm{kkal}$, protein $42 \mathrm{~g}$, vitamin A $558 \mathrm{RE}$, vitamin C 47,2 mg, dan Fe $11,8 \mathrm{mg}$. Dibandingkan baseline, kecukupan energi meningkat dari 76,4 persen menjadi 98,3 persen, dan kecukupan protein dari $73,5 \%$ menjadi 87,1 persen. Asupan vitamin A relatif tetap, tetapi menurun untuk asupan vitamin C (10-20 mg) dan zat besi (1-3 mg) per hari, meskipun secara statistik tidak signifikan $(p<0,05)$. Berdasarkan kategori persen AKG (tanpa suplemen), ditemukan masih sekitar 35-94 persen sampel yang mengalami defisiensi asupan vitamin $A, C$ dan zat besi.

Asupan zat besi dari konsumsi pangan relatif tidak terjadi peningkatan, namun karena terdapat peningkatan asupan energiprotein kemungkinan akan memperbaiki optimalisasi metabolisme zat besi (Beard 2000). Tabulasi silang menggunakan cut-off 70 persen dan 80 persen AKG menunjukkan tingkat kecukupan energi cenderung tidak berpengaruh terhadap perubahan $\mathrm{Hb}$, STfR dan SF. Demikian pula hasil Ancova, tingkat kecukupan energi dan zat gizi tidak mempengaruhi peningkatan $\mathrm{Hb}$, STfR dan SF $(p>0,05)$. Pada studi ini nampaknya peningkatan asupan zat gizi makro terbatas hanya memperbaiki indikator besi fungsional (hemoglobin). Perbaikan cadangan besi akan terjadi apabila disertai peningkatan asupan vitamin seperti folat, vitamin A, C, dan B12 seperti pada kelompok yang memperoleh suplemen B-MV.

Kepatuhan konsumsi makanan tambahan (PMT) juga cukup besar, yaitu rata-rata 86 persen. Tingkat kepatuhan konsumsi PMT diantara ketiga kelompok perlakuan sangat baik, dan dengan analisis Ancova peubah ini tidak signifikan pengaruhnya terhadap perbaikan status besi $(p>0,05)$. Selama suplementasi, rata-rata asupan energi dan zat gizi dari PMT adalah 296 kkal, protein 5,1 g, vitamin A $68 \mathrm{RE}$, vitamin B12 0,2 mg, vitamin C 9,4 mg, Fe 2,4 $\mathrm{mg}$.

\section{Kepatuhan Konsumsi Kapsul}

Rata-rata konsumsi kapsul sebanyak 22 dari 25 butir yang diberikan selama suplementasi (92\%). Analisis Ancova, peubah kovariat kepatuhan minum kapsul tidak menjadi confounders terhadap hasil perbaikan biomarker $(p>0,05)$, karena cakupan kepatuhannya pada ketiga kelompok sudah cukup tinggi dan tidak berbeda diantara ketiga kelompok $(p>0,05)$. Penilaian secara subyektif tentang manfaat 
minum kapsul adalah 27 persen menyatakan jarang sakit, dan $34 \%$ tidak cepat lelah; sedangkan keluhannya 47 persen sering mengantuk, dan 43 persen nafsu makan meningkat. Jawaban sampel tersebut antara kelompok kontrol dan perlakuan relatif seragam (placebo effect). Untuk itu agak sulit disimpulkan terhadap jawaban tersebut apakah karena perbedaan perlakuan kapsul atau oleh faktor eksternal lainnya (kegiatan akademik dan non-akademik).

Pada studi ini drop-out karena keluhan minum kapsul sangat rendah $(2,7 \%)$, yaitu ditemukan sebanyak tiga sampel (B-F) dan satu sampel (B-MV), yang menunjukkan rendahnya efek samping kapsul ini sehingga tingkat compliance cukup tinggi. Studi Tee et al. (1999) menunjukkan bahwa penggunaan dosis Fe $60 \mathrm{mg}$ (dibanding $120 \mathrm{mg}$ ) dapat menurunkan keluhan efek samping dan meningkatkan penerimaan suplemen, namun masih memberikan efikasi yang sama terhadap peningkatan hemoglobin dan feritin.

\section{Status Gizi Besi}

Hasil studi ini menunjukkan bahwa prevalensi anemia di kalangan mahasiswi sebelum suplementasi adalah 25,1 persen (kategori sedang). Selain anemia masih menjadi masalah di kalangan mahasiswi, juga ditemukan banyak yang menderita deplesi zat besi (ID) dan defisit besi eritropoiesis (IDE), yaitu berturut-turut 41,7 persen dan 40,1 persen. Prevalensi defisiensi gizi besi (IDA) sebelum suplementasi sebesar 16,4 persen yang menunjukkan bahwa sekitar 65 persen anemia di kalangan remaja putri disebabkan oleh defisiensi zat besi. Angka ini lebih besar dari asumsi INACG (2003) dan WHO (2004) bahwa 50 persen kejadian anemia akibat defisiensi zat besi.

Efikasi suplemen terhadap status gizi besi dianalisis dari tiga indikator $\mathrm{Hb}$, STfR, dan SF yang masing-masing mencerminkan tahapan defisiensi zat besi didalam tubuh. Peningkatan kadar hemoglobin pada ketiga kelompok relatif sama, yaitu antara 8-11 g/l (Tabel 4). Rata-rata penambahan $\mathrm{Hb}$ setelah dikoreksi (adjusted) dengan peubah kovariat tetap tidak berbeda nyata diantara ketiga kelompok $(p>0,05)$, yaitu peningkatan untuk B-MV 10,4 g/l. Peningkatan $\mathrm{Hb}$ tersebut cukup besar, meskipun kondisi sampel pada baseline tidak anemia $(\mathrm{Hb}=126,2 \mathrm{~g} / \mathrm{l})$. Studi lainnya dengan sampel remaja wanita anemia, peningkatan hemoglobin ini sama dengan studi Tee et al. (1999) yang meningkat $11,4 \mathrm{~g} / \mathrm{l}$. Namun peningkatan $\mathrm{Hb}$ studi ini masih lebih tinggi dibandingkan dengan studi lainnya dengan sampel tidak anemia, yaitu sebesar 0,5 - 6,8 g/l (Angeles-Agdepa et al. 1997; Zhu dan Haas 1998; Ahmed et al. 2005). Pada studi lainnya dengan sampel remaja wanita menderita anemia, peningkatan $\mathrm{Hb}$ antara 17,3 - 21,0 g/l (Dillon, 2005). Kadar $\mathrm{Hb}$ awal secara signifikan berpengaruh terhadap peningkatan $\mathrm{Hb}(\mathrm{p}<0,05)$, yaitu yang memiliki kadar $\mathrm{Hb}$ awal lebih rendah peningkatannya lebih besar.

Apabila peningkatan hemoglobin kelompok perlakuan (B-F dan B-MV) dikoreksi dengan kelompok kontrol, maka peningkatan kadar Hb hanya 2-3 g/l karena peningkatan $\mathrm{Hb}$ pada kontrol sekitar $8,3 \mathrm{~g} / \mathrm{l}$. Tidak semua studi suplementasi, kelompok kontrol mengalami kenaikan hemoglobin, bahkan pada beberapa studi terjadi penurunan $\mathrm{Hb}(-0,8$ sampai $-6,1 \mathrm{~g} / \mathrm{l})$, yaitu pada studi Soekarjo et al. (2004), AngelesAgdepa et al. (1997), Zhu dan Haas (1998). Pada studi ini, peningkatan kadar $\mathrm{Hb}$ kontrol cukup tinggi dibandingkan studi lain 1,2-1,6 g/l (Ahmed, Khan, Jackson 2001; Zavaleta, Respicio, Garcia 2000), karena kontrol tidak semata-mata berupa plasebo tetapi juga memperoleh PMT.

Suplementasi kapsul B-MV pengaruhnya sangat signifikan terhadap serum transferin reseptor (STfR). Pada kelompok B-MV meskipun rata-rata STfR sebelum suplementasi lebih buruk, tetapi sesudah suplementasi perbaikan status atau penurunan STfR (-3,8 mg/l) lebih signifikan dibandingkan kelompok B-F $(-1,3 \mathrm{~m} / \mathrm{l})$ dan kontrol $(+0,5 \mathrm{mg} / \mathrm{l})$ (uji Anova, $p<0,05)$ (Tabel 5). Hasil analisis Ancova, selisih STfR pada B-MV sebesar -4,2 mg/l jauh lebih rendah dibandingkan kedua kelompok lainnya. Hal tersebut karena STfR awal pada kelompok B-MV jauh lebih tinggi dibandingkan dua 
kelompok lainnya. Penambahan STfR secara signifikan dipengaruhi oleh status $\mathrm{Hb}$ dan STfR awal $(p<0,05)$, hal ini menegaskan kembali STfR merupakan indikator yang sensitif terhadap awal defisit besi, namun relatif tidak terpengaruh perubahan cadangan besi (Baynes 1995).

Penambahan keempat vitamin pada BMV di atas nampaknya sangat efektif untuk meningkatan simpanan zat besi (storage), dan kemudian akan memperbaiki kompartemen besi transpor (transferin) yang ditunjukkan oleh penurunan STfR. Prevalensi iron deficiency anemia (IDE) juga menurun sangat signifikan yaitu sebesar 35 persen pada B-MV, dibandingkan dengan B-F 9 persen dan kontrol 2 persen.

Serum feritin merupakan indikator yang sensitif untuk mengukur cadangan besi tubuh (iron store). Konsentrasi SF relatif sama sebelum suplementasi, namun sesudah suplementasi kapsul B-MV berhasil meningkatkan SF lebih tinggi dibandingkan B-F (Tabel 6). Penambahan vitamin A, C, dan B12 membantu proses absorpsi besi dan sintesa feritin didalam hati dan darah (meningkatkan iron storage). Suplemen B-F berhasil meningkatkan SF 4,2 ug/l, sedangkan B-MV meningkatkan SF jauh lebih tinggi $(11,0 \mathrm{ug} / \mathrm{l})$. Meskipun dengan uji Anova antara kelompok B-F dan B-MV kenaikan SF tidak berbeda nyata $(p>0,05)$, tetapi perbedaan kontrol dengan B-MV sangat nyata $(p<0,05)$. Hasil analisis setelah dijustifikasi peubah kovariat, peningkatan SF pada kelompok B-MV juga lebih tinggi dibandingkan kedua kelompok lainnya 13,3 ug/l. Peningkatan feritin antara 7,6-23,3 ug/l juga ditemukan pada studi lain seperti Angeles-Agdepa et al. (1997), Tee et al. (1999), Zhu dan Haas (1998), Ahmed et al. (2005), dan Dillon (2005). Peningkatan SF ini secara signifikan juga ditentukan oleh kondisi SF awal $(p<0,05)$ dan $\mathrm{Hb}$ awal $(p<0,01)$. Dengan suplementasi, peningkatan besi cadangan akan lebih tinggi jika kadar SF awal lebih rendah dan kadar $\mathrm{Hb}$ awal lebih tinggi. Studi Tee et al. (1999) menunjukkan kenaikan serum feritin sangat dipengaruhi oleh SF awal.
Setelah suplementasi tidak terjadi penurunan prevalensi deplesi besi pada kontrol, dan penurunan terjadi pada kelompok B-F dan B-MV yaitu 15,3 persen dan 10,6 persen. Proses replenish (pengisian cadangan besi) banyak terjadi pada kelompok B-MV $(76,4 \%)$, kemudian BF $(72,7 \%)$ dibandingkan dengan kontrol $(54,5 \%)$. Ini juga menunjukkan bahwa pengisian cadangan besi didalam tubuh lebih efektif dengan penambahan suplemen (BMV maupun B-F) dibandingkan kontrol.

Metode lain untuk menilai status besi adalah dengan cara menghitung simpanan besi. Cara ini memerlukan analisis dengan menggunakan indikator secara bersamaan, yaitu STfR dan SF. Estimasi terhadap jumlah besi didalam tubuh dilakukan dengan menggunakan formula Cook et al. (2003) yang dihitung dari rasio STfR dan SF. Jumlah besi didalam tubuh $(\mathrm{mg} / \mathrm{kg})=-[\mathrm{log}$ (STfR:SF) - 2,8229]: 0,1207. Nilai positif artinya terjadi surplus zat besi didalam simpanan, dan nilai negatif menunjukkan defisit zat besi didalam jaringan. Tabel 7 menunjukkan bahwa sebelum suplementasi, kelompok kontrol mempunyai simpanan besi yang paling tinggi $(2,7 \mathrm{mg} / \mathrm{kg})$ diantara ketiga kelompok. Simpanan besi kelompok B-MV secara signifikan lebih rendah $(1,0 \mathrm{mg} / \mathrm{kg})$ dibandingkan dengan kontrol dan B-F (1,9 $\mathrm{mg} / \mathrm{kg}$ ). Tetapi setelah suplementasi kondisinya menjadi terbalik, yaitu kelompok B-MV simpanan besinya paling tinggi yaitu menjadi $3,5 \mathrm{mg} / \mathrm{kg}$. Kapsul B-F berhasil meningkatkan simpanan besi sebesar 1,5 $\mathrm{mg} / \mathrm{kg}$ (dari 1,9 menjadi $3,4 \mathrm{mg} / \mathrm{kg}$ ), tetapi pada kontrol justru menurun dari 2,7 menjadi $2,3 \mathrm{mg} / \mathrm{kg}$. Pada studi ini akhirnya dibuktikan bahwa dengan menambahkan vitamin $A, C$, B12, dan asam folat (kapsul B-MV) akan lebih meningkatkan simpanan besi (storage compartment). Jika dibandingkan dengan data NHANES, rata-rata nilai simpanan besi sebesar $5,5 \pm 3,4 \mathrm{mg} / \mathrm{kg}$, dan nilai tersebut semakin meningkat dengan bertambahnya usia.

Kondisi anemia dan defisiensi besi pada mahasiswi dikawatirkan akan berpengaruh terhadap kemampuan fisik (working capacity) dan prestasi akademik karena akan 
menurunkan kapasitas oksidatif jaringan, kemampuan angkut oksigen, dan kemampuan sistem saraf. Review 29 penelitian oleh Haas dan Brownlie IV (2001), sampel anemia (berat/ringan) berkaitan erat dengan kapasitas aerobik dan endurance, demikian pula sampel yang defisiensi besi (anemia/non-anemia) meskipun pengaruhnya lebih ringan. Studi Halterman et al. (2001) pada anak sekolah, resiko anak yang defisiensi besi 2,3-2,4 kali nilai matematika lebih rendah dibandingkan yang normal.

\section{KESIMPULAN}

\section{Kesimpulan}

1. Rata-rata kadar hemoglobin $(\mathrm{Hb})$ sebelum suplementasi pada pada ketiga kelompok tidak berbeda nyata, yaitu 126,9 $\pm 15,0 \mathrm{~g} / \mathrm{l}$. Kenaikan kadar hemoglobin setelah suplementasi perbedaannya tidak nyata, yaitu mengalami kenaikan antara 9-11 g/l ( $p>0,05)$.

2. Peningkatan serum transferin reseptor (STfR) lebih tinggi pada kelompok B-MV dibandingkan B-F, namun perbaikan tersebut tidak terjadi pada kontrol. Sebelum suplementasi, STfR paling tinggi pada B-MV $(10,4 \pm 1,7 \mathrm{mg} / \mathrm{l})$ dari pada B-F $(6,9 \pm 1,7 \mathrm{mg} / \mathrm{l})$ dan kontrol $(5,1 \pm 1,7 \mathrm{mg} / \mathrm{l})$. Penurunan STfR secara signifikan lebih besar pada kelompok B-MV $(-4,2 \quad \mathrm{mg} / \mathrm{l})$ dibandingkan B-F $(-1,3 \quad \mathrm{mg} / \mathrm{l})$ dan kontrol +0,9 mg/l.

3. Peningkatan serum feritin (SF) pada kelompok B-MV lebih tinggi dibandingkan kelompok B-F dan kontrol. Sebelum suplementasi, kadar serum feritin (SF) pada ketiga kelompok tidak berbeda nyata yaitu 18,3 $\pm 15,9$ ug/l. Kenaikan SF kelompok B-MV (+13,3 ug/l) secara signifikan lebih tinggi dari pada kelompok B-F $(+5,1 \mathrm{ug} / \mathrm{l})$ dan kontrol (-1,7 ug/l).

\section{Saran}

\begin{abstract}
Perbaikan status besi, perlu dipertimbangkan tidak hanya dengan pemberian besi-folat saja, tetapi dengan menambahkan vitamin lainnya (vitamin $A, C$, B12). Penambahan vitamin tersebut selain dapat meningkat hemoglobin, juga akan memperbaiki status besi pada sistem transpor dan simpanan (storage) tubuh. Oleh karena itu untuk perbaikan status besi melalui suplementasi perlu dipertimbangkan penggunaan besi-multivitamin untuk menghasilkan output status besi yang maksimal, dan kemungkinan efek positif dalam jangka panjang.
\end{abstract}

\section{UCAPAN TERIMA KASIH}

Ucapkan terima kasih disampaikan kepada SEAFAST Center IPB, yang telah memberi kesempatan kepada penulis untuk menjadi anggota kegiatan Feeding Program for Needy Students. Selain itu juga disampaikan terima kasih kepada PT. Kimia Farma Bandung yang membantu formulasi dan pengadaan kapsul suplementasi.

\section{RUJUKAN}

1. Ahmed F, et al. 2005. Efficacy of twice weekly multiple micronutrient supplementations for improving the hemoglobin and micronutrient status of anemia adolescent schoolgirls in Bangladesh. Am J Clin Nutr 82:829835.

2. Allen LH. 2004. Folate and vitamin B12 status in the Americas. Nutrition Reviews 62(6):S29-S33.

3. Allen L, Casterline-Sabel J. 2001. Prevalence and causes of nutritional anemias. Di dalam Ramakrishnan U. 2001. Nutritional Anemias. CRC Press. USA

4. Angeles-Agdeppa I, et al. 1997. Weekly micronutrient supplementation but iron stores in female Indonesian adolescents. Am J Clin Nutr 66:177-83.

5. Baynes RD. 1996. Assessment of iron status. Clinical Biochemistry, Vol. 29, No.29. No.3. pp 209-215. 
6. Beard JL. 2000. Iron requirements in adolescent females. J. Nutr 130:440S442S.

7. Beard JL. 2001. Functional consequences of nutritional anemia in adults. Di dalam Ramakrishnan ed: Nutritional Anemias. CRC Press. USA

8. Cook JD, Flowers $\mathrm{CH}$, Skikne BS. 2003. The quantitative assessment of body iron. BLOOD, 101(9):3359-3364

9. Departemen Kesehatan RI. 2007. Gizi dalam Angka. Jakarta.

10. Dillon DHS. 2005. Nutritional health of Indonesian adolescent girls: the role of riboflavin and vitamin $\mathrm{A}$ on iron status [disertasi]. Netherlands: Wageningen University.

11. Ekstrom EC. 2001. Supplementation for nutritional anemias. Di dalam: Ramakrishnan U, editor. Nutritional Anemias. Florida:CRC Press:129-152

12. Haas JD, Brownlie IV T. 2001. Iron deficiency and reduced work capacity: a critical review of the research to determine a causal relationship. J. Nutr: 676S-690S.

13. Halterman JS et al. 2001. Iron deficiency and cognitive achievement among school-aged children and adolescent in the United States. PEDIATRIC 107(6):1381-1386.

14. INACG [International Nutritional Anemia Consultative Group]. 2003. Integrating programs to move iron deficiency and control anemia forward. Report of the 2003 INACG symposium, Marrakesh, Marocco.

15. INACG [International Nutritional Anemia Consultative Group]. 2004. Iron deficiency in early life: challenges and progress. Report of the 2004 INACG international anemia consultative group symposium, Lima, Peru.

16. Kanani SJ, Poojara RH. 2000. Supplementation with iron and folic acid enhances growth in adolescent Indian girls. J. Nutr 452S-455S.
17. Khatib $L$ et al. 2006. Folate deficiency is associated with nutritional anaemia in Lebanese women of childbearing age. Public Health Nutrition: 9(7), 921-927.

18. Permaisih D, Herman S. 2005. Faktorfaktor yang mempengaruhi anemia pada remaja. Bul.Penel. Kesehatan 33(4):162-171

19. Soekarjo DD, et al. 2004. Effectiveness of weekly vitamin A (10 $000 \mathrm{IU})$ and iron (60 mg) supplementation for adolescent boys and girls through schools in rural and urban East Java, Indonesia. European Journal of Clinical Nutrition 58: 927-937.

20. Tee E, et al. 1999. School-administered weekly iron-folate supplements improve hemoglobin and ferritin concentrations in Malaysian adolescent girls. $A m \mathrm{~J}$ Clin Nutr 69:1249-56.

21. WHO [World Health Organization]. 2004. WHO/CDC expert consultation agrees on best indicators to assess iron deficiency, a major cause of anemia.

22. http://www, who.int/ mediacentre/news/notes/2004/anemia/e n [20 Mei 2005]

23. Zavaleta N, Respicio G, Garcia T. 2000. Efficacy and acceptability of two iron supplementation schedules adolescent school girls in Lima, Peru. J. Nutr 130:462S-464S.

24. Zhu IY, Haas JD. 1998. Response of serum transferring receptor to iron supplementation in iron-depleted, nonanemic women. Am J Clin Nutr 67:2715

25. Wessling-Resnick M. 2000. Iron transport. Annu. Rev. Nutr.20:129-151

26. Beard JL, Dawson H, Pinero DJ. 1996. Iron metabolism: a comprehensive review. Nutrition Review 54 (10): 295317

27. Ahmed F, Khan MR, Jackson AA. 2001. Concomitant supplemental vitamin A enhances the response to weekly supplemental iron folic acid in anemia 
teenagers in urban Bangladesh. Am J Clin Nutr 74: 108-15

28. Erhard JG, et al. 2004. Combined measurement of ferritin, soluble transferrin receptor, retinol binding protein, c-creative protein by inexpensive, sensitive and simple sandwich Enzyme-linked immunoabsorbent assay technique. J. Nutr. 34: 3127-3132

Tabel 1

Kelompok perlakuan dan jenis suplemen

\begin{tabular}{|l|l|}
\hline \multicolumn{1}{|c|}{ Kelompok Perlakuan } & \multicolumn{1}{c|}{ Jenis suplemen } \\
\hline Kontrol & Plasebo (selulosa) \\
\hline Besi-folat (B-F) & Zat besi $60 \mathrm{mg}$ dan asam folat $250 \mathrm{ug}$ \\
\hline Besi-multi vitamin (B-MV) & $\begin{array}{l}\text { Zat besi } 60 \mathrm{mg} \text {, asam folat } 800 \mathrm{ug}, \text { vitamin A } 4200 \mathrm{ug} \text {, vitamin C } 500 \mathrm{mg}, \\
\text { vitamin B12 16,8 ug }\end{array}$ \\
\hline
\end{tabular}

Tabel 2

Karakteristik sampel sebelum suplementasi

\begin{tabular}{|c|c|c|c|c|c|c|c|}
\hline \multirow[t]{2}{*}{ Karakteristik Sampel } & \multicolumn{6}{|c|}{ Kelompok } & \multirow[t]{2}{*}{ p } \\
\hline & \multicolumn{2}{|c|}{ Kontrol } & \multicolumn{2}{|c|}{ B-F } & \multicolumn{2}{|c|}{ B-MV } & \\
\hline Umur (thn) & \multicolumn{2}{|c|}{$18,6 \pm 0,6^{a}$} & \multicolumn{2}{|c|}{$18,6 \pm 0,6^{a}$} & \multicolumn{2}{|c|}{$18,5 \pm 0,5^{\mathrm{a}}$} & 0,578 \\
\hline Tot.pengel (Rp/bl) & 467.288 & $\pm 173.270^{a}$ & 493.431 & $\pm 188.283^{a}$ & 470.432 & $\pm 172.631^{\mathrm{a}}$ & 0,650 \\
\hline Peng. pangan (Rp/bl) & 267.949 & $\pm 105.397^{\mathrm{a}}$ & 275.566 & $\pm 92.155^{a}$ & 261.544 & $\pm 78.986^{\mathrm{a}}$ & 0,255 \\
\hline Makanan & 208.791 & $\pm 72.486^{\mathrm{a}}$ & 218.164 & $\pm 68.450^{\mathrm{a}}$ & 211.072 & $\pm 58.450^{\mathrm{a}}$ & 0,697 \\
\hline Minuman & 33.423 & $\pm 41.725^{\mathrm{a}}$ & 33.966 & $\pm 31.840^{\mathrm{a}}$ & 30.177 & $\pm 23.648^{a}$ & 0,777 \\
\hline Jajanan & 28.430 & $\pm 25.991^{\mathrm{a}}$ & 28.525 & $\pm 26.066^{a}$ & 23.451 & $\pm 19.343^{a}$ & 0,590 \\
\hline $\mathrm{BB}(\mathrm{kg})$ & \multicolumn{2}{|c|}{$46,7 \pm 6,2^{a}$} & \multicolumn{2}{|c|}{$47,0 \pm 5,8^{a}$} & \multicolumn{2}{|c|}{$46,7 \pm 5,0^{\text {a }}$} & 0,950 \\
\hline TB (cm) & \multicolumn{2}{|c|}{$153,5 \pm 5,6^{a}$} & \multicolumn{2}{|c|}{$154,1 \pm 5,6^{a}$} & \multicolumn{2}{|c|}{$153,5 \pm 5,3^{a}$} & 0,769 \\
\hline IMT $\left(\mathrm{kg} / \mathrm{cm}^{2}\right)$ & \multicolumn{2}{|c|}{$19,8 \pm 2,0^{a}$} & \multicolumn{2}{|c|}{$19,7 \pm 1,9^{a}$} & \multicolumn{2}{|c|}{$19,8 \pm 1,9^{a}$} & 0,979 \\
\hline
\end{tabular}

${ }^{a}$ Pada baris yang sama, huruf yang sama menunjukkan tidak terdapat perbedaan yang nyata $(p>0,05)$.

Tabel 3

Rata-rata asupan dan tingkat kecukupan energi dan zat gizi sebelum dan sesudah suplementasi

\begin{tabular}{|l|c|c|c|c|c|c|c|}
\hline \multirow{2}{*}{ Energi dan Zat Gizi } & \multicolumn{9}{|c|}{ Kelompok } & \multirow{2}{*}{ B-F } \\
\cline { 2 - 8 } & \multicolumn{9}{|c|}{ Kontrol } & \multicolumn{3}{|c|}{ B-MV } & \\
\hline Sebelum: & 1431 & $(74,4)^{\mathrm{a}}$ & 1509 & $(78,0)^{\mathrm{a}}$ & 1502 & $(76,7)^{\mathrm{a}}$ & 0,302 \\
\hline Energi (kkal) & 34,8 & $(71,2)^{\mathrm{a}}$ & 36,7 & $(75,2)^{\mathrm{a}}$ & 36,5 & $(74,1)^{\mathrm{a}}$ & 0,357 \\
\hline Protein (g) & 541 & $(95,1)^{\mathrm{a}}$ & 699 & $(122,9)^{\mathrm{a}}$ & 622 & $(108,0)^{\mathrm{a}}$ & 0,156 \\
\hline Vitamin A (RE) & 51 & $(68,0)^{\mathrm{a}}$ & 60 & $(79,6)^{\mathrm{a}}$ & 67 & $(89,1)^{\mathrm{a}}$ & 0,227 \\
\hline Vitamin C (mg) & 13,0 & $(45,4)^{\mathrm{a}}$ & 14,0 & $(53,8)^{\mathrm{a}}$ & 14,1 & $(54,2)^{\mathrm{a}}$ & 0,302 \\
\hline Zat besi (mg) & \multicolumn{7}{|c|}{} \\
\hline Sesudah: & 1727 & $(93,0)^{\mathrm{a}}$ & 1875 & $(99,6)^{\mathrm{b}, \mathrm{c}}$ & 1897 & $(101,5)^{\mathrm{c}}$ & 0,019 \\
\hline Energi (kkal) & 39,8 & $(82,6)^{\mathrm{a}}$ & 42,6 & $(88,1)^{\mathrm{a}, \mathrm{b}}$ & 43,4 & $(89,8)^{\mathrm{b}}$ & 0,101 \\
\hline Protein (g) & 505 & $(95,0)^{\mathrm{a}}$ & 589 & $(108,5)^{\mathrm{a}}$ & 572 & $(103,7)^{\mathrm{a}}$ & 0,485 \\
\hline Vitamin A (RE)
\end{tabular}




\begin{tabular}{|l|c|c|c|c|c|c|c|}
\hline Vitamin C (mg) & 43 & $(56,8)^{\mathrm{a}}$ & 45 & $(59,9)^{\mathrm{a}}$ & 53 & $(71,4)^{\mathrm{a}}$ & 0,480 \\
\hline Zat besi (mg) & 11,8 & $(45,4)^{\mathrm{a}}$ & 11,9 & $(45,7)^{\mathrm{a}}$ & 11,8 & $(45,5)^{\mathrm{a}}$ & 0,994 \\
\hline
\end{tabular}

1 nilai rata-rata asupan dan () untuk tingkat kecukupannya

a,b,c Pada baris yang sama, huruf yang tidak sama menunjukkan terdapat perbedaan yang nyata $(p<0,05)$.

Tabel 4

Rata-rata kadar hemoglobin sebelum dan sesudah suplementasi

\begin{tabular}{|l|r|l|r|l|r|l|c|}
\hline \multirow{2}{*}{$\begin{array}{c}\text { Keadaan } \\
\text { Suplementasi }\end{array}$} & \multicolumn{5}{|c|}{ Kelompok $(\mathrm{g} / \mathrm{l})$} & \multirow{2}{*}{$\mathrm{p}$} \\
\cline { 2 - 8 } & \multicolumn{2}{|c|}{ Kontrol } & \multicolumn{2}{|c|}{ B-F } & \multicolumn{2}{c|}{ B-MV } & \\
\hline Sebelum & 126,1 & $\pm 14,7^{\mathrm{a}}$ & 124,4 & $\pm 13,5^{\mathrm{a}}$ & 128,1 & $\pm 0,8^{\mathrm{a}}$ & 0,279 \\
\hline Sesudah & 134,4 & $\pm 14,9^{\mathrm{a}}$ & 135,6 & $\pm 14,0^{\mathrm{a}}$ & 138,6 & $\pm 13,5^{\mathrm{b}}$ & 0,208 \\
\hline Selisih & 8,3 & $\pm 15,4^{\mathrm{a}}$ & 11,2 & $\pm 12,6^{\mathrm{a}}$ & 10,5 & $\pm 12,0^{\mathrm{a}}$ & 0,425 \\
\hline
\end{tabular}

${ }^{\mathrm{a}}$ Pada baris yang sama, huruf yang sama menunjukkan tidak berbeda nyata, Uji Anova $(p<0,05)$.

Tabel 5

Rata-rata kadar STfR sebelum dan sesudah suplementasi

\begin{tabular}{|l|r|l|r|l|r|l|l|}
\hline \multirow{2}{*}{$\begin{array}{c}\text { Keadaan } \\
\text { Suplementasi }\end{array}$} & \multicolumn{5}{|c|}{ Kelompok (mg/l) } & \multirow{2}{*}{$\mathrm{P}$} \\
\cline { 2 - 7 } & \multicolumn{2}{|c|}{ Kontrol } & \multicolumn{2}{|c|}{ B-F } & \multicolumn{2}{c|}{ B-MV } & \\
\hline Sebelum & 5,8 & $\pm 3,2^{\mathrm{a}}$ & 7,9 & $\pm 4,4^{\mathrm{b}}$ & 11,8 & $\pm 5,5^{\mathrm{c}}$ & 0,000 \\
\hline Sesudah $^{*}$ & 6,3 & $\pm 3,4^{\mathrm{a}}$ & 6,6 & $\pm 2,6^{\mathrm{a}}$ & 8,0 & $\pm 3,3^{\mathrm{b}}$ & 0,030 \\
\hline Selisih & 0,5 & $\pm 2,7^{\mathrm{a}}$ & $-1,3$ & $\pm 3,7^{\mathrm{b}}$ & $-3,8$ & $\pm 6,5^{\mathrm{c}}$ & 0,000 \\
\hline
\end{tabular}

${ }^{a, b, c}$ Pada baris yang sama, huruf yang tidak sama terdapat perbedaan yang nyata, Uji Anova $(p<0,05)$. " berbeda nyata antara B-F dan B-MV, Uji Anova $(p<0,10)$

Tabel 6

Rata-rata kadar SF sebelum dan sesudah suplementasi

\begin{tabular}{|l|r|l|r|l|r|l|c|}
\hline \multirow{2}{*}{$\begin{array}{c}\text { Keadaan } \\
\text { Suplementasi }\end{array}$} & \multicolumn{5}{|c|}{ Kelompok (ug/l) } & \multirow{2}{*}{$p$} \\
\cline { 2 - 7 } & \multicolumn{2}{|c|}{ Kontrol } & \multicolumn{2}{|c|}{ B-F } & \multicolumn{2}{c|}{ B-MV } & \\
\hline Sebelum & 22,5 & $\pm 18,2^{\text {a }}$ & 27,4 & $\pm 28,8^{\text {a }}$ & 30,6 & $\pm 24,7^{\text {a }}$ & 0,340 \\
\hline Sesudah & 23,6 & $\pm 21,4^{\text {a }}$ & 31,6 & $\pm 23,8^{\mathrm{b}}$ & 41,6 & $\pm 37,6^{\mathrm{b}}$ & 0,002 \\
\hline Selisih & 1,1 & $\pm 12,0^{\text {a }}$ & 4,2 & $\pm 25,7^{\text {a }, \mathrm{b}}$ & 11,0 & $\pm 25,3^{\mathrm{b}}$ & 0,058 \\
\hline
\end{tabular}

$a, b$ Pada baris yang sama, huruf yang tidak sama terdapat perbedaan yang nyata, Uji Anova $(p<0,05)$.

Tabel 7

Rata-rata simpanan zat besi sebelum dan setelah suplementasi menurut kelompok ${ }^{1}$

\begin{tabular}{|c|r|c|r|c|r|r|c|}
\hline \multirow{2}{*}{ Suplementasi } & \multicolumn{5}{|c|}{ Kelompok } & \multirow{2}{*}{ Total } \\
\cline { 2 - 7 } & \multicolumn{2}{|c|}{ Kontrol } & \multicolumn{2}{|c|}{ B-F } & \multicolumn{2}{c|}{ B-MV } & \\
\hline Sebelum $(\mathrm{mg} / \mathrm{kg})$ & 2,7 & $\pm 4,3^{\text {a }}$ & 1,9 & $\pm 4,1^{\text {a }}$ & 1,0 & $\pm 3,7^{\text {b }}$ & 0,104 \\
\hline Setelah $(\mathrm{mg} / \mathrm{kg})$ & 2,3 & $\pm 4,3^{\text {a }}$ & 3,4 & $\pm 3,9^{\text {a }}$ & 3,5 & $\pm 3,9^{\text {a }}$ & 0,211 \\
\hline
\end{tabular}

$\bar{x} \pm \mathrm{Sd}$

a,b Pada baris yang sama, angka dengan huruf yang tidak sama menunjukkan terdapat perbedaan yang nyata antar kelompok (Uji Anova, p<0,05). 